University of Louisville

ThinkIR: The University of Louisville's Institutional Repository

Faculty Scholarship

$1-2003$

\title{
Never Let the Truth Stand in the Way of a Good Story: A Work for Three Voices
}

Bronwyn T. Williams

University of Louisville

Follow this and additional works at: https://ir.library.louisville.edu/faculty

Part of the English Language and Literature Commons, Journalism Studies Commons, and the Rhetoric and Composition Commons

Original Publication Information

Williams, Bronwyn T. "Never Let the Truth Stand in the Way of a Good Story: A Work for Three Voices."

2003. College English 65(3): 290-304.

This Article is brought to you for free and open access by ThinkIR: The University of Louisville's Institutional Repository. It has been accepted for inclusion in Faculty Scholarship by an authorized administrator of ThinkIR: The University of Louisville's Institutional Repository. For more information, please contact thinkir@louisville.edu. 


\section{Never Let the Truth Stand in the Way of a Good Story: A Work for Three Voices}

\section{Bronwyn T. Williams}

\section{THE JOURNALIST}

$\mathrm{M}$ y father always said, "Never let the truth stand in the way of a good story." It was certainly a maxim he took to heart. In his world I was a six-foot-five-inch high school basketball dynamo certain to be named to the All-Conference Team. He was a veteran of the 101st Airborne and had parachuted into Normandy on D-Day with General John Gavin. And when I married he told people my wife was descended from ancient Irish nobility. (Closer to reality I was a six-foot benchwarmer who got cut from the team my senior year because of a combination of shoddy ball-handling skills and a poorly hidden contempt for the coach. My wife's lineage is certainly Irish, but can claim only rural poverty as her Hibernian heritage. And my father was in the Army in the Second World War and did land at Omaha Beach, as a sergeant in the finance division a month after D-Day.)

It used to make me furious when my father would embellish his stories to make them better. "That is not what happened," I would fume. "What is wrong with just telling the truth?" I couldn't understand why he would feel compelled to lie. After all, he had no tolerance for my lying. When I went through a stage at about age ten of making up one whopper after another, both to entertain and to get out of trouble, his response was strict and inflexible: I must not lie; honorable men tell the truth. If I questioned him about this seeming inconsistency-for he was an honorable and compassionate man-he would smile at me, repeat his maxim about good stories, and leave me to rage inside at how my life was being misrepresented to others.

Bronwyn T. Williams is an assistant professor in the English department of the University of Louisville. He is the author of Tuned In: Television and the Teaching of Writing. Along with creative nonfiction, he teaches and writes about issues of literacy, popular culture, identity, and cross-cultural communication.

College English, Volume 65, Number 3, January 2003 
The eventual effect on me was to instill a ferocious desire to know what really happened in any situation. If I had to tell a story, others who heard it would find out the truth of what happened. I owed the truth to them, and to the people involved in the story. I worked on my memory. I rehearsed and re-rehearsed the events that occurred so that I would be able to tell a story completely and accurately. I tried to remember, for any given day, what I ate, what I wore, where I was when I had a particular conversation. This work on memory could make me insufferable to family and friends, particularly if I thought their accounts of events deviated even slightly from what I knew to be the truth.

At the same time that I sought new levels of intolerance for people who embellished the truth, or couldn't be bothered to remember the truth, the world around me was dominated by news of the Vietnam War and Watergate. Even as an elementary school student, I began to understand that most adults around me were beginning not to believe the official narratives the military establishment spun about the war. When Watergate came along, my father, a New Deal Democrat with a visceral dislike for Richard Nixon, would rail at the lies and distortions of that "lying SOB, who would say anything to get himself off the hook." Eventually the generals, the White House officials, and even the president were caught in their lies and disgraced. And who were the people instrumental in striking these critical blows for the truth?

Journalists.

It was journalists, to my mind, who had told the truth about the war, journalists who had broken through the White House stone walls about Watergate. I read All the President's Men in junior high school—and then saw the movie—and I knew what I was going to do with my life. I was going to work for the truth. I was going to be the eyes and the ears of society and tell people what was going on in the world in a clear-eyed, unbiased, and honorable way. We were believers, those of us who entered journalism schools in the seventies. We entered our journalism classes and worked on the student newspapers with deep-rooted cynicism toward anything said by a person in authority and an equally deep-rooted faith that only we had the skillsand, more to the point, the integrity-to collect the facts and tell the people the truth. I believed in the journalistic cliché that my job was to comfort the afflicted and afflict the comfortable.

One of my first journalism professors, Mary Benedict, was a short, thick woman who almost disappeared behind the desk when she sat down. Even so, her force of personality was in inverse proportion to her size and she could intimidate the most self-assured nineteen-year-old with a quick, unforgiving glare. She would parade before us in class, perforating the air with her finger and shouting, "Accuracy, accuracy, accuracy! For a reporter there is one standard and one standard only: accuracy, 
accuracy, accuracy. You must get all the facts, get them right, and get them to the readers as clear as crystal."

Accuracy, accuracy, accuracy. It was my creed. I worked relentlessly to be as accurate as possible. Upon graduation I took a job at a paper in a big city in the Midwest. Not all of my motivations were altruistic. Even then I knew that some of it was about my ego as a writer, my desire to be close to the excitement of the world, my love of writing and working with words. There always remained, however, an obsession with trying to find out the straight story and tell that to others. I regarded myself, without irony, in the service of the readers who couldn't be present with me at events and to whom I owed an accurate reporting.

People tell stories, relate the events of their lives, in part because those stories are true. They want other people to know what happened. And they want to hear about what happened as close to the truth as possible. If the president is shot, they want to know the facts. If there is a new budget plan, they want to know the numbers. (Even today, as a thoroughly postmodern academic, sometimes I need to know that a story is true. If the window gets broken I don't want to discuss the social construction of truth with my sons; I want to know who did it and how it happened.) As I later worked as an editor I became known as a meticulous fact-checker and as having a skill for identifying inaccuracies and inconsistencies in reporters' stories (a skill that does not necessarily endear one to all reporters, by the way).

I despised politicians who wouldn't tell the truth and adored the ones who did. I held a special contempt for Ronald Reagan, and not simply because of the gross unfairness of his political beliefs. What enraged me about Reagan, to the point where I could no longer watch him on television, was his carelessness with the truth, his easy willingness to embellish, twist, and create stories he then passed off as accurate and true. If I despised Reagan I was even angrier at Janet Cooke, and in recent years at Patricia Smith, Mike Barnicle, Jeff Jacoby, and others, who, in the pages of daily newspaper journalism, have created characters, invented quotations, plagiarized, and fabricated events for their articles and columns. Even if they were telling stories I sympathized with on a political level, they had betrayed the fundamental trust of journalists. They had told stories, told lies, in the guise of the truth.

Even worse, and this was something I knew viscerally long before I had worked it out in my head, I hated the liars because I knew that somewhere there might be a person who was being lied about. If a person's thoughts or actions or words were fabricated, or even if the person was simply misquoted, people would regard what they read as the truth. The real people in the story would be hurt by what was printed and yet have no effective way to respond. It is painfully disorienting to see yourself presented to the world in a way that makes you unrecognizable to yourself (as I was once in a national news magazine). To see yourself in such a funhouse 
mirror is to yearn for equal time, to long to be able to track down every person whom you see reading the story, snatch it from their hands, and say, "Look, that's not quite right. The truth of the matter is ..."

A friend from a different journalism school told of an assignment for which the students were to interview and write profiles of each other. Years later she remained indignant that she was described in her partner's story as being "impish." Though she is short and slight, she had never, she maintained, been "impish."

Yet, even as I argued and struggled to make my own work and the work of others more accurate and truthful, I realized, even as an undergraduate, that there were substantial holes in my worldview. I knew that the history of journalism, a history that included writers such as Chekhov, Zola, Stanley, and even my college hero Ernie Pyle, included writing that was not so voiceless or perhaps so careful with the facts. These writers often told their stories from a subjective, personal point of view that included opinion and interpretation, that told individual stories in a way that moved the heart as well as the head.

I admit to having looked for facts to fit the phrase or hook that would make my story more effective. I once typed the phrase "men in their ice-cream suits on their way to church" because I knew it would work in the story I was writing; then I went looking to see at least one man in such a summer suit. I have told journalism students to look for the human face in their stories and to write in ways that make that face come alive, even as I wonder whom they will infuriate by describing as the equivalent of "impish."

More sinister was the confidence, the dark glee, that I felt in knowing that I could get a story out of almost anyone. I was good at seducing my sources. I didn't take the Mike Wallace approach and verbally pummel people until they collapsed on camera. Instead I knew I could rely on my sincerity (yeah, I could fake that) and my then-boyish face to get people to trust that all I wanted was for the truth to come out. "I want to be able to tell your side of the story. It deserves to be told and I can only do that if you talk to me." I could be shameless in pursuit of a story. Of course it wasn't all cynical manipulation. I did want them to have their say, to tell their stories. I would rationalize my seductions by telling myself that the people I was talking to wanted to tell their stories, too; they would be grateful at the chance to be heard and to have their words passed on to the world. What I didn't bother to emphasize was that $I$ would be the storyteller. I would control how the story was told. I would control how they would be represented. Their words. My story.

\section{ThE WRITER}

My father always said, "Never let the truth stand in the way of a good story." I believed him and I took it to heart. I am a good liar, maybe even a great one. I can 
tell intricate tales with only a passing resemblance to the truth and never crack a smile or flutter an eyelid. When I was about ten years old I began to lie about everything. What I'd done in school, who took my brother's money, what TV show I was watching, whether I had actually seen a story on the news about a man arrested for trying to hit birds with his car. I lied for the pure pleasure of creating a story I knew would entertain my audience, gather attention for me, and hide my true thoughts and feelings.

My parents were simultaneously baffled and frustrated by my constant fabrications and stories (they kept referring to them as lies). "Why are you lying about things that don't even matter?" my mother would say. "There's just no point to it." And my father would give me yet another serious lecture on the need for the honorable man always to tell the truth. I wish I could say that their wisdom made me stop. Mostly it made me work at being a better liar. I paid more attention to what was tipping them off, moderated the scope of my lies, and tried to understand what worked best with my audience. (I learned at an early age the importance of the rhetorical context.) A former girlfriend told me I had all the makings of a great spy. It was not a compliment.

Eventually I stopped lying so much. At first it wasn't so much because of my parents' admonitions as it was the realization that eventually the truth did catch up with me in some measure and that my subsequent stories would diminish in impact. A fancy way of saying that I recognized myself as the boy who cried wolf. (And, yes, I began to understand that telling the truth was honorable and did require a working moral compass of sorts.) I was also able to stop lying in my daily life, however, because I began to realize that there were culturally acceptable ways to lie and even be applauded for lying. I would write fiction. If I were to embellish a story to make it better on the page, to dramatize a situation or to get the best laugh, it would be worth it for my pleasure and the pleasure of my audience. I began to write stories and poems and songs. Each more dreadful than the next, but I delighted in their fabrication.

While I learned to love writing, I wasn't convinced I was really any good at it. Like many writers who also lack the courage to follow the craft, I went into journalism because it seemed one way to keep writing and eating at the same time. Yet even as I liked being a journalist I yearned to unleash on the world my insights beyond the mere facts I collected. I wanted to write prose that was more memorable than serviceable. In the ongoing arguments in journalism school as to who was a better reporter and who a better writer, each side of the equation had a particular set of implications. If you were a better writer you were more concerned with craft and beauty and the telling of the story than you were with the tracking down of the details and the facts. I wanted people to think of me as more writer than reporter even if that implied that I might be less scrupulous with facts. 
This perspective often put me at odds with my journalism professors, and later with my editors. When, in a magazine writing course, I tried writing part of a story about a knife attack from the points of view of the assailant and the victim-based on interviews I had conducted-my professor, Dick Tobin, the former editor of the Saturday Review, told me I had crossed the line.

"You can't pretend to know more than you know," he said "The reader will know that you have to be making at least some of it up and then the reader won't know when to trust you."

I argued with him that I was searching for a deeper truth. "The essence of what I am writing is true," I said.

When later, at a newspaper, I wrote part of a story about an urban renewal project in a small city in the first person, the editor handling the story chided me for putting my own opinions in the story.

"People don't want your judgments, they want the facts," she said.

"But they get my judgments every time I write. It's just that this time I'm being upfront about it."

Though there was a great deal about journalism that appealed to me, I began to tire of producing story after story that was a string of facts, anecdotes, and quotations, written in a hurry and from an ostensibly detached point of view that did little to situate either me as the writer or the sources I was writing about. I wanted to say what needed to be said, but couldn't be said by the facts alone, with grace and elegance and a definitive point of view that was clear from the beginning of the story.

I began with fiction because every journalist wants to be a novelist. (If that meant that I could indulge the latent liar in me, so much the better.) Besides, I thought fiction avoided the clumsy attempts at psychoanalysis that marked so much of literary journalism (what we then called creative nonfiction) of the time. If you were going to interpret and embellish at all, then why not go all the way and employ all the tools of the novelist or short-story writer? Fiction certainly wouldn't keep you from drawing on autobiography or real events. By fabricating your own stories, though, you avoided issues of credibility with your audience. And you avoided hurting those people you represented in your writing.

Or so I thought. I had shown my brother a short story I was writing. Although the setting was similar to a day on the ocean I had spent with him and his girlfriend of the time, that was, as far as I was concerned, the extent of the similarities. "But I didn't say any of that," he said. I assured him that the character wasn't he and that I had just used the setting as a catalyst for the story. He protested, however, that the similarities were both numerous and potentially embarrassing. I tried to reassure him.

"Even if I had written about you, which I didn't, the names are changed, the descriptions and events are different. Who would know? Who could be hurt?" I said.

"I could be." 
I was shaken by his insistence and his genuine hurt. With each piece I wrote I began to wonder about the people who would see themselves in my writing. Who might be hurt? What obligations did I have to those who were the subjects of my writing?

These thoughts came back to me when, several years ago, the controversy over Binjamin Wilkomirski's book, Fragments, erupted. Wilkomirski had written what he presented as memoir of his childhood in concentration camps during the Holocaust. It was a compelling book and I was completely engaged in his writing. When evidence emerged that caused the factual basis of the memoir to be questioned I found myself, like many other readers, angry at him for passing off his stories as the truth. I felt duped, betrayed, and as if the real stories of children who had suffered had been somehow damaged by his duplicity. Why, now that I had discovered that his stories were simply that, stories, did they carry less weight, less impact, than if I had read the work as fiction? And who could be hurt in these situations?

Such questions began to press more insistently on me as I found my writing moving more and more from fiction to that amorphous realm of "creative nonfiction." I do believe that there is a difference in reading fiction and reading nonfiction. In the same way that the journalist in me wants to know the truth of what happened, there is a power in the retelling of real events in real lives that is different from the power of fiction. Different and important. We tell stories to one another, to understand one another, in part because they are true. That is, after all, why creative nonfiction appeals to us. The nonfiction writer says to the reader, "Such things can happen, have happened, and as human beings we must struggle to make meaning from them." Though there are moving stories, poems, and films about wars, the short, detailed dispatches of a writer such as Ernie Pyle are gripping not only for their artistry, but because they are glimpses into the unpredictable events of real lives and moments.

Yet for all the power that reading about real events holds for me, reading creative nonfiction often makes me cringe. It's not the revelations writers make about themselves that make me uncomfortable; it's what the writers reveal about others. I can't but wonder what must their children/parents/spouses/ friends think about being written of in this way? Even if the stories are true, it is their lives that are on display as much as the writers'. Such concerns gnaw at me even as I write this essay. I wonder what Mary Benedict and my brother and others about whom I write would think of how I have portrayed them. I consider not mentioning names, or using pseudonyms, or using composite characters, and then begin to flinch at the thought of bending the truth. When a friend published a piece that was critical of her sister I asked what she thought her sister's response to the portrayal would be.

"Oh, she'll never read this," she said. "I would never publish something like this in a place where I thought she might read it." 
For me the answer was not good enough. (And because it was not, I have been careful, as my unsatisfactory compromise, not to use this friend's name in my essay, though she will no doubt recognize herself here if she reads this piece. Perhaps I am already bending the truth too much.) Lee Gutkind, the editor of Creative Nonfiction, maintains that the "creative" part of creative nonfiction refers to the craft, not the information: "Creative doesn't mean making up. It must be understood that there's no place for invention in this genre" (qtd. in Redfield 37). I am with him there until I hear from a writer such as Patricia Hampl, who says that anyone writing memoir "must live with a version that attaches us to our limitations, to the inevitable subjectivity, of our points of view" (32) or Jocelyn Bartkevicius, who writes that "memory, the mind's path, enacts wonders, and the creative nonfiction writer's work is not to reason those wonders away with mathematical formulae, but to embrace them, to recreate layer after layer of incongruity" (254). Their words also touch a truth that I cannot ignore.

I am fully aware of the shortcomings of memory, as the work of psychologists such as Elizabeth Loftus have demonstrated time and again. I also know that any teller of story shapes that story. My friend Tim, a journalist who covers national politics, and I argue about how much the writer shapes the story. He maintains that he can portray, accurately, what he has seen, which then gives the readers of his work a clear picture of what actually happened. I argue that it is his perspective only that he can offer and that to imagine it as anything else is just fooling himself. We disagree. Still, I know that he is covering national figures who have ample opportunities to reach the public and shape their own stories through multiple media.

For me, for most writers, it is different. Who is implicated in the shaky memories I write about? Who is hurt by my lies? Whose story am I allowed to tell? And why am I allowed to tell it, simply because I am a writer?

\section{The Teacher}

My father always said, "Never let the truth stand in the way of a good story." I say this to my creative nonfiction course students and they laugh appreciatively, as I expect them to. It's a good line and it both presents an image of my father as a yarnspinning rogue and seems to give them, as writers, implicit permission not to worry too much over the facts in their writing.

As the chuckling subsides I say, "Yes, it's a good line isn't it? But what are the implications? What is it really like to have to deal with someone whom you are never entirely sure is telling you the straight story? How would you feel if someone you knew was telling stories here, in the Humanities Building, about seeing you at a party last night, but was at the least stretching the truth about your behavior and at 
worst making parts of it up out of thin air? How would you feel if you were interviewed for a piece of journalism and the reporter decided to embellish your quotations and attribute thoughts and actions to you that hadn't happened?"

They shift uncomfortably in their chairs. I've set them up, I know, but I don't want to make this easy for them. I hope that the discussion will begin to emerge in a moment when I admit to my own deep ambivalences about this subject. On the one hand I have been telling them all semester about accuracy, about the necessity of research and fact checking when writing nonfiction. "Making even one mistake will undermine your credibility with at least one reader, probably more," I tell them. "Scrupulous accuracy and attention to the truth is the only way to establish credibility, and credibility is the only reason anyone should keep reading your work." I show them examples of other writers who have made mistakes, both large and small, and explain how that makes me question their other claims and evidence. I show them examples of writers whose arguments, which seem so authoritative on the surface, rest uneasily on unstated but arguable assumptions and oddly interpreted evidence. I talk about the need to read and write critically, with one eye always turned to the unspoken assumptions underlying every argument and piece of evidence. I tell them this and I believe it.

Now I tell them that there is no such thing as the "truth." What we call truth consists of the social constructions we agree on as a culture. I talk about postmodern theory. I talk about the slipperiness of language, the unreliability of memory. I give them example after example of times and places where what was considered to be the incontrovertible truth was later shown to be a far shakier structure of opinions and perceptions. "It's not that people are trying to lie," I tell them, "It is simply that we all construct our perceptions and memories based on our experiences, our desires, and our cultural expectations." I talk with them about the importance of avoiding the easy complacency of thinking one knows the "truth" and I try to make them understand how high the stakes are when we construct the truth in a way that lets us sleep soundly at night. I tell them this and I believe it.

Student responses vary. Some of them, deeply uncomfortable with ambiguity, either cling fiercely to the idea of knowable and unalterable truths or retreat to an easy cynicism in which they purport to regard every statement as a manipulative lie. It reminds me of a recent exchange about creative nonfiction on a compositionoriented e-mail list. One writer, defending the need for attending to the truth in writing nonfiction, cited in a post Scott Russell Sanders's irritation at having the work in his essays regarded as fiction. In the section alluded to, Sanders argues that it does matter that he wrote a work of nonfiction. "I meant to preserve and record and help give voice to a reality that existed independently of me" (203). The first post brought a quick response, however, from another writer who dismissed Sanders's argument as a naïve lack of awareness of the constructed nature of the "truth." 
Both arguments are too easy, too definitive. And both arguments leave out something essential: the obligation of writers to those they write about.

At a recent CCCC panel I sat in the audience and listed to a discussion about creative nonfiction among some writers whose work I have admired over the years. I was grateful to have such a discussion about creative nonfiction on the program and delighted to see that the audience was standing-room-only. Yet as the conversation progressed, as the panelists talked of questions of representation, I found myself increasingly uncomfortable.

"These [family stories] are our stories too and they deserve to be told."

"People who don't do this kind of writing are more afraid of the truth than we are."

"The true story must be told."

"For the story that works well, nothing is off limits."

"I write because I must represent the truth and the consequences be damned."

What, for me, was left unsaid throughout the session was the question of power. Of course, family stories belong to all members of a family. It is only the writer, however, who gets to define those stories-even the stories that are true-in print for an audience of strangers to see. It is only the writer who decides which stories that larger audience "deserves" to hear. And, if those who don't do the writing are more afraid of the "truth" that appears in print it is, perhaps, a well-founded fear. They know that they will not have the power or opportunity to respond, to present their stories. Pain is not always a social construction.

To be fair, and true, there was also a great deal of discussion about compassion and privacy. (And, to be fair, I have not named names here. I tell myself it is not to embarrass the people about whom I write. Or did I not do so because I am a coward, simply less powerful than they are? Would I have used names had they been my students?) Even as the session ended with resounding applause, however, the question of the writer's power, and the ethical questions such power posed when considering who decided a story "deserved" to be told, never emerged directly. I was reminded of Ruth Behar's description of her internal conflict at telling stories of her family as an essential and inescapable part of her academic work, all the while knowing how much the telling of these stories to strangers would upset her parents-if they only knew. Behar can't resolve the conflict for herself and instead writes of "keeping every word hidden from my father and mother, withholding from them the knowledge that I am flying around the country inscribing the story of our dissolution as a family ever more irrevocably into the academy" (82).

When I talked with friends after the session few seemed as bothered as I was by what was unacknowledged about the power of the writer. One friend said to me, "But everyone knows that truth is a construct, so no one would read a piece of 
nonfiction without that in mind." I wondered if I could really read that way, though. As well versed in postmodern theory as I try to be, I know that when I read the work of a good creative nonfiction writer, I find myself swept up in a story upon which I confer the power of accuracy, the power of the truth. If I had to question every fact or observation I encountered, what would be the point of reading nonfiction?

When I was a graduate student my seminar on research methods addressed at length issues of representation and ethics, particularly when it came to working with students as research subjects. There has been an increasingly important body of work about such issues, including such valuable books as Mortensen and Kirsch's Ethics and Representation in Qualitative Studies of Literacy, and our class discussions were productive and nuanced. It was a great class.

About two thirds of the way through the semester we departed from reading either articles about or examples of composition research and read Jon Krakauer's Into the Wild. Krakauer's book is splendid. It is the complex story of a young man who, seeing himself on a journey of discovery, eventually starves to death in the Alaskan wilderness. It is a moving account that combines journalism, history, nature and travel writing, memoir, and cultural critique and, in the end, offers few easy answers. Krakauer comes across as a writer of integrity who is unafraid of ambiguity and complexity. It is an excellent example of what I see as the genre of creative nonfiction.

Yet the day we discussed it in class was deeply frustrating for me. In the book Krakauer interviews the young man's parents and is often critical in his interpretation of their lives. In the class my fellow students joined in the criticism. While I agreed with the criticism, given Krakauer's portrayal, I pointed out that it was his interpretation that we were reading. The parents had no chance to tell their story.

"But they talked to him," one classmate said. "If they hadn't liked what he was doing they wouldn't have had to talk to him. They had a choice."

"It might not have been much of a choice," I said. "If he stands there and says, 'I'm going to write a book about your son whether you talk to me or not. Do you want to have your say?' what kind of choice does that give them?"

"I don't think people talk to writers unless they know it is in their best interests."

"Have you ever watched 60 Minutes? Why would anyone talk to Mike Wallace? But they do time and time again. You might think that it's easy to say no, but I'm telling you, when I was a journalist I could have gotten anyone in this room to talk to me about just about anything. And I was nothing all that special as a reporter. And, whether you talk to me or not, you're mine to represent as I please."

It was a bad rhetorical move on my part because it moved the conversation toward who might or might not be susceptible to reporters. That wasn't my point. 
What I couldn't seem to do that day was to convince those in the room of the power of the journalist, of the nonfiction writer. What troubled me the most was not that people disagreed with me, but that I sensed in some of my colleagues a veiled arrogance that while journalists were capable of manipulating people, of seducing and misrepresenting them, they as composition scholars were already operating on a higher ethical plane and needn't worry about those issues as overtly.

I am similarly troubled when I look at creative nonfiction syllabi or course offerings for creative nonfiction programs and rarely see readings or courses that deal with ethics and representation. This is particularly the case when creative nonfiction courses are housed in English departments. I worry that when we teach students in creative nonfiction about the social construction of truth, about the slipperiness of memory, we want to open the door for a more thoughtful critique of culture and society, but risk letting in instead an easy cynicism and a willingness to be sloppy about research and facts-as well as a potential for self-absorption. At the same time I worry that if we tell our students to write the truth and damn the consequences, an attitude shared by far too many in journalism as well, we are teaching them to ignore or, at best, rationalize the casualties that mount beside the road that leads to such truth.

As I noted above, as a professional field composition continues to contemplate and struggle with issues of power and representation in research and writing. For all the time we spend on such issues for our research, however, we are much less likely to address it as thoroughly in our writing courses, particularly at the undergraduate level. Creative nonfiction is an important genre and I delight both in writing it and in teaching it to students. It is important and fitting that composition studies, rooted as it is in part in the personal essay and in research writing, be involved in the teaching, research, and discussion about the development of the genre. In this work on creative nonfiction, then, it is essential that we address the issues of power and representation and the ethical concerns that such issues entail. Such questions must be inextricable from our teaching of creative nonfiction as a craft.

Scott Russell Sanders, in his essay "The Singular First Person" that I quote above, also writes that his desire to write nonfiction, and have it recognized as such, grows from a responsibility "to the truth as known by other people. I wanted to speak directly out of my own life into the lives of others" (203). I want my students to understand that "truth" is elusive, constructed, and that writing nonfiction can blur the already fuzzy lines between truth and a good story. At the same time I want them to have a respect for the best honesty they can muster and, most of all, to have a deep and constant consideration for the consequences of their writing on the people represented by their words. 


\section{IN UNISON}

My father always said, "Never let the truth stand in the way of a good story." Perhaps, then, it was inevitable that I end up wandering the terrain of creative nonfiction.

As a fiction writer I am too much of a polemicist to be anything but an essayist at heart; and as an essayist I am prone to stretch the truth as far as I can.

As a journalist I worry over the social construction of truth and what parts of stories never get told.

As a composition scholar I am interested in the individual writer and the role of the personal and the power of narrative.

I have seen and lamented, in the manner of a low-level malcontent, literary journalism marginalized in journalism schools, the true essay marginalized in literature-heavy English departments, journalism marginalized in composition programs, creative writing marginalized by all of the above. I reject what often seems the prevailing wisdom that journalism is not about beauty, that fiction is not about the truth or the social construction of culture, that composition should be concerned with rhetoric and the social construction of academic discourse before it is about the personal and creative in all writing. I know that my work in creative nonfiction is informed by all of these different forms and approaches to writing. If from journalism I maintain an interest in hearing the stories of others and a respect for accuracy and for the effect of my work on living, breathing people, fiction writing has provided me with a respect for craft and for aesthetics, and a desire for narrative and for telling a story in such a way that is gratifying and that keeps my audience engaged. It is all colored by my work in critical theory about the social construction of the truth and identity - and the obligations those constructions create for a writer-and connected by work in composition studies and my interests in how writing happens and how we can teach others to write effectively about their lives and ideas.

Creative nonfiction often seems problematic in the English departments because of the ways it sprawls across the contested academic terrains of creative writing, composition, journalism, and literature. When I was at one university a literature professor taught a course in autobiographical criticism, a composition professor taught a seminar in the uses and teaching of the personal, a creative writing professor taught a course in fiction writing, and two professors with backgrounds in journalism taught courses in the form and theory of nonfiction and in advanced essay writing, respectively. Though these were all good courses and exceptional teachers, the work in each course went on in different degrees of isolation from the other courses, even though there were natural intersections of the conversations and writing that happened in the courses. As so often happens, however, a complex combination of dis- 
ciplinary differences, turf battles, terminological screens, and just plain overwork kept a more fruitful conversation about the nature and implications of creative nonfiction from happening in the department.

These arbitrary, historical, yet real divisions are obviously more permeable than we often assume them to be. Creative nonfiction, as a genre and an approach to writing that clearly transcends the boundaries, is an important place to begin seeing the work of writing and the teaching of writing as touching all that we do in the study and teaching of literacy. We need not only to address creative nonfiction in each area of English studies, but also to talk across our divisions to complicate and enrich our definitions and perceptions of the genre. Central to each discussion, however, should be a commitment to remembering that the work of creative nonfiction is not constrained to writing about abstract texts and subjects. There is always interpretation and subjectivity; but, in the end, the subjects and sources about whom we write are also known as people.

\section{CodA}

My father never said, "Never let the truth stand in the way of a good story." Though he certainly might have. He did embellish stories about me, about himself, about others that he knew, and it did both enchant and infuriate me. But I made up the quotation when I spoke at his funeral, as a way of turning his storytelling into an amusing and endearing character trait. I wanted people to remember him as a smart, compassionate, and charismatic man. He was all of those things. The "truth" was, however, that his stories helped him, in years in which he suffered from devastating bouts of depression and unemployment in a world that viewed both as moral failings, to face that world, in which he felt he had failed as a provider and as a father. Even as I write this, cutting as close to the bone of truth as I dare, I wonder about what I am doing to his reputation. Was it kinder to him to stick with the story I told at his funeral? I would never have written this while he was alive. Yet would it be kinder to my mother, who is still alive, not to produce in print for the whole world to see (or at least the readership of College English - which is not exactly the same thing) the darker fires of pain and humiliation that drove my father's storytelling? Will I show this essay to my mother and my family? Like Ruth Behar, how do I confront the conflict between writing these words for an audience of my professional peers because I think this is an important issue to discuss and knowing that my words might cause pain to others, pain that I cannot predict and certainly do not intend? Have I ended this essay this way because it makes me look like a good and moral and self-reflective writer, even as I exploit my father's pain and my mother's grief? Am I being honest, or just finding a great twist for the ending of this essay?

I like to think that I raise these questions because they trouble me and are 
indicative of the tensions that exist among my journalist, writer, and teacher selves. And I think that in composition, when we discuss teaching creative nonfiction, we spend too little time on the effects of our work on those we write about, on the ethics of reportage and observation and representation. It is easy to wrap ourselves in the comforting blankets of the social construction of truth and postmodern theories of subjects and subjectivities and not feel the chilly breezes of pain and hurt that may come from those we write about.

When I was a young reporter working on the state desk of a metropolitan newspaper I was often called up late at night or on weekends to cover breaking news stories - often a euphemism for disasters of one kind or another. I didn't mind. In calling me the paper ensured that some reporter with a family would be able to sleep and I recognized the justice in that. I would dutifully pack up my notebooks, hop in the car, and drive off to the scene of a fire or a tornado and get down to the business of taking notes and interviewing disaster officials, rescue workers, and survivors.

Early on, however, I decided that I would try my best not to intrude too much on the grief of the victims of disasters. I would leave my notebook in my pocket when I approached somebody standing next to the tornado-strewn rubble of what used to be a house, and just talk to him or her for a while to determine whether there was a story she or he wanted to tell, before I would even ask for an interview. Usually when I asked for an interview people said yes, and I think I often got good material because I took the time to talk first. I took the time to consider the impact of my work on this person's life.

Sometimes, though, in my better moments, I would leave my notebook in my pocket and walk away.

\section{Works Cited}

Bartkevicius, Jocelyn. "The Landscape of Creative Nonfiction." The Fourth Genre: Contemporary Writers offon Creative Nonfiction. Ed. Robert L. Root, Jr., and Michael Steinberg. Boston: Allyn, 1999. 252 58.

Behar, Ruth. "Writing in My Father's Name: A Diary of Translated Woman's First Year." Women Writing Culture. Ed. Ruth Behar and Deborah A. Gordon. Berkeley: U of California P, 1995. 65-82.

Hampl, Patricia. "Memory and Imagination." I Could Tell You Stories: Sojourns in the Land of Memory. New York: Norton, 1999. 21-37.

Krakauer, Jon. Into the Wild. New York: Anchor, 1996.

Mortensen, Peter, and Gesa E. Kirsch, eds. Ethics and Representation in Qualitative Studies of Literacy. Urbana, IL: NCTE, 1996.

Redfield, Sarah Heekin. "Surveying the Boundaries: An Inquiry into Creative Nonfiction." Poets and Writers 27.5 (1999): 36-41.

Sanders, Scott Russell. "The Singular First Person." Secrets of the Universe: Scenes from the Fourney Home. Boston: Beacon, 1991. 187-204.

Wilkomirski, Binjamin. Fragments: Memories of a Wartime Childhood. Trans. Carol Brown Janeway. New York: Schocken, 1996. 